\title{
Modern methods of teaching foreign languages to the university
}

\author{
D.R.Boychayeva ${ }^{1}$, D.A. Rahmanova ${ }^{2}$, M.B. Yuldasheva ${ }^{3}$ \\ ${ }^{1,2,3}$ Teachers of Namangan State University, Uzbekistan \\ Email:boychayeva_d@umail.uz
}

\begin{abstract}
This article discusses the methods of the "public" and "consultant", developed by the American psychologist K. Kurran based on the advantages of these methods.

Keywords: "community" method, suuggerodic method, method of "quiet" training, method of reliance on physical actions.
\end{abstract}

\section{INTRODUCTION}

The concept of the "community" method (the "adviser" method) was introduced by the American psychologist C. Kurran, which is based on the humanistic approach to learning and the psychological theory of the "adviser". The essence of this theory is that people need help from a psychologist and his participation is desirable in any kind of social activity of a person, including in education. This method of "community" is determined by the following features: According to the humanistic approach to learning, students play an important role in organizing the course. They determine the content of the training and choose the appropriate pace for them and the mode of work. The teacher fulfills the role of an "adviser", which tells the student the phrases they need to conduct conversations in a foreign language. The teacher should not be a leader or supervisor of the teaching process, nor should students be actively involved in the communication process if they do not want it. The training program is not specifically established, and students can choose the topic that interests them. An important learning method is the translation from the native language of a foreign language.

\section{MAIN PART}

The learning process is organized as follows way. Students work in a group, sit around the table and discuss the topic of the conversation in their native language. Then the communication is gradually conducted in a foreign language. The teacher does not participate in the conversation and watches the discussion, and then joins in this process, offering equivalents in a foreign language. Students repeat the phrases and then write them down on a tape recorder. The community-community methodologists believe that it has a truly humanistic character, is aimed at the student's personality and is characterized by a lack of stress in the teaching process. The application of this method requires special training of teachers, since they are not psychologists and can apply the appropriate psychological methods. The suggest opedic method, which was developed under the guidance of psychiatrist G. Lozanova, derives its name from the term "suggestions I "-a science of suggestion. An important feature of this method is the activation of memory reserves, increasing the intellectual activity of students, the use of suggestion.

Lazanov believes that the main means of activating reserve capabilities are the following: Authorities. The teacher plays an important role in the learning process. The teacher should have certain qualities that contribute to increasing his authority. It is necessary to create in the group such an environment, as a result of which students are taught in conditions favorable to learning, mutual trust, are freed from tension. This means that it is necessary to use the gestures, facial expressions, intonation in order to influence the interlocutor, to arrange it to yourself. 


\section{THEORETICAL BACKGROUND}

According to the suggestion method, it is necessary to listen in a certain way. Important requirements are imposed on the intonation and rhythm of the sounding material. Text material should sound in a certain rhythm accompanied by specially selected music. The above-mentioned method of G.Lozanova initiated the development of methods in methodology, the most important of which are: the method of activating the reserve capabilities of the individual and the collective G.A. Kitaigorodskaya, the immersion method (A.S. Plesnevich), hypnopedy (E.V. Sirovsky), and others. Supporters of the Lozanov method developed many provisions. Thus, G.A. The method of activating the reserve capabilities of the personality of introduces the Learner center approach into the intensive methods of personality and considers learning as a process of communication and dialogue that has the character of mutually mediated activity between the teacher and students when the teaching plays a leading role in comparison with training. Kitaigorodskaya revises the content of the term "authority" and speaks about the creative role of the teacher, the creation of trust relationships in the group and between the teacher and the group that contribute to increasing the motivation and emotional tone of the audience, provide disclosure of the student's individual reserves. The revitalization method is based on the following principles: - the phased concentric organization of classes, - the global use of all means of influencing the psyche of students, - oral advancement, - the use and The interaction of role and personality elements in learning. Many provisions of this method are widely used in the practice of teaching foreign languages. The suggest opedic method is of interest, since it is aimed at teaching communication in the shortest possible time, and the result is noticeable after a few lessons. and the negative aspects of the above methods. The students' record is full of mistakes, which makes it difficult to understand the communication process. In addition, the use of intensive methods requires careful preparation of teachers. It is appropriate to distinguish between the concepts of "intensive methods" and "intensification of the learning process."

\section{RESULTS}

Computer assisted language learning is based on an ethnically oriented approach, which has made computer training popular. There are the following groups of programs: - training programs for individual work at home or in computer classes, aimed at mastering grammatical forms, lexical units, speech patterns, as well as programs for teaching reading and writing, - text programs for individual, pair and group work, allowing to differentiate the text: put punctuation marks, regroup sentences, - game programs built on problem situations and promoting motivation. Most believe that computer programs are entertaining, interesting, motivate, but still they do not form a communicative competence and can not replace the teacher. A consciously oriented approach is based on the nalexic and grammatical forms of language and is based on the inductive method of mastering the language. This approach is largely similar ssoznatelnosopostavitelnym method that assumes chtomyshlenie in all languages the same, only different forms of its expressions. The most important advantage of this approach is bessoznatelnoeovladenie language ispolzovanieizuchaemyh phenomena in communication and the use of authentic materials. But it is necessary to point out also the negative aspects: exaggeration of the role of linguistic knowledge, operations of comparison, comparison and analysis. The method of communicative tasks (Task based learning) solves a number of communicative tasks offered by the teacher. Students perform speech and non-verbal actions, come into contact with each other. They can often use only speech, but also physical actions, gestures, mimicry. The curricula, which are used according to this method, provide for the selection of communicative tasks, but they do not select the language material.

The method of communicative tasks is in the development stage, the process is not yet completed, which allows us to introduce refinements and changes. Neuro-Linguistic Programming is a science that studies the attainments of personality, skills of leadership, and also guides the teaching of a foreign language, revealing and activating the individual's capabilities in the process of verbal communication. Neurolinguistic programming embraces a way of thinking, modeling in this thought process, the emergence and the time Itie senses and belief.

The founders of neurolinguistic programming were John Grinder, assistant lecturer at the Department of Linguistics, and Richard Bandler, a student of the Faculty of Psychology and Mathematics, who tried to "model" the activities of the three psychotherapists. Imibili Fritz Perls, experienced psychotherapist, founder of helstat therapy, Virginia Satir, a researcher in family therapy and Milton 
Erickson, the famous hypnotherapist, the founder of modern hypnotherapy. Grinder and Bandler were trying to reproduce the same models of communication that these talented students used in order to subsequently apply them in their work.

The linguistic approach reveals a relation to linguistic models that decides the main role in achieving relationships between people and form the core of communicative processes.

\section{CONCLUSION}

Programming defines such a way by which we express our thinking in order to achieve the intended goals. Theory of the Multiplied Intelligence (The Theory of Multipl eIntelligencies) was created by Howard Gardner, who is one of the most famous scholars in the field of education in the United States on issues of cognitive development and neuropsychology. His book Boundaries of Thinking: Theory of Intellectual Intelligence, made G. Gardner the most famous representative of the educational theory and practice and won him world fame. Gardner noted an overview of autonomous intellectual abilities: linguistic, logical-mathematical, spatial, musical, physical-physical, interpersonal, personal and natural. The latter makes it possible to identify, categorize and apply the properties of the environment. Gardner also emphasizes the identification of new intellectual abilities, if they meet the criteria worked out.

\section{REFERENCES}

1. G.Lozanov "Suggestology" Sofia: Science and Art. -1971

2. Kitaigorodskaya G.A. The method of intensive instruction in foreign languages. M .: High School., 2010

3. Railways. "NLP: effective leadership skills" St. Petersburg. -2009

4. Блохин Н.В. Психологические основы модульного профессионально-ориентированного обучения: Методическое пособие. - Кострома: Изд-во КГУ им. Н.А.Некрасова, 2003.

5. Кукосян О.Г., Князева Г.Н. Концепция модульной технологии обучения в системе дополнительного профессионального образования. - Краснодар.2001.

6. Муравьева А.А., Кузнецова Ю.Н. Организация модульного обучения, основанная на кометенциях. Пособие для преподавателей. М., 2005. 